\title{
On the determination of the global cloud feedback from satellite measurements
}

\author{
T. Masters \\ School of Engineering and Applied Science, UCLA, Los Angeles, California, USA \\ Correspondence to: T. Masters (tmasters@ucla.edu) \\ Received: 21 January 2012 - Published in Earth Syst. Dynam. Discuss.: 3 February 2012 \\ Revised: 2 August 2012 - Accepted: 7 August 2012 - Published: 23 August 2012
}

\begin{abstract}
A detailed analysis is presented in order to determine the sensitivity of the estimated short-term cloud feedback to choices of temperature datasets, sources of top-ofatmosphere (TOA) clear-sky radiative flux data, and temporal averaging. It is shown that the results of a previous analysis, which suggested a likely positive value for the short-term cloud feedback, depended upon combining all-sky radiative fluxes from NASA's Clouds and Earth's Radiant Energy System (CERES) with reanalysis clear-sky forecast fluxes when determining the cloud radiative forcing (CRF). These results are contradicted when $\triangle \mathrm{CRF}$ is derived using both all-sky and clear-sky measurements from CERES over the same period. The differences between the radiative flux data sources are thus explored, along with the potential problems in each. The largest discrepancy is found when including the first two years (2000-2002), and the diagnosed cloud feedback from each method is sensitive to the time period over which the regressions are run. Overall, there is little correlation between the changes in the $\triangle \mathrm{CRF}$ and surface temperatures on these timescales, suggesting that the net effect of clouds varies during this time period quite apart from global temperature changes. Given the large uncertainties generated from this method, the limited data over this period are insufficient to rule out either the positive feedback present in most climate models or a strong negative cloud feedback.
\end{abstract}

\section{Introduction}

The cloud feedback is one of the largest sources of uncertainty when trying to determine the global surface temperature response to a doubling of $\mathrm{CO}_{2}$, and is the primary discrepancy leading to differing climate sensitivities in the global climate models (Bony et al., 2006; Bender, 2011). While many improvements have been made in the way the cloud radiative forcing can be estimated and constrained (Allan, 2011), the response of this net cooling effect of clouds to temperature changes (that is, whether the cooling effect becomes stronger or weaker as the climate warms) still remains largely uncertain. Within the context of this paper, we use the typical notion of a cloud feedback, whereby it is considered negative if the amount of radiation escaping to space due to clouds (either by reflecting more solar radiation, or allowing more outgoing longwave radiation - OLR - through the atmosphere) increases with an increase in temperature, and positive if an increase in temperature results in the opposite, thereby exacerbating the warming. All radiative fluxes presented in this paper are thus shown with a positive value indicating a downward flux towards the surface, including $\mathrm{CRF}$ and $\Delta R_{\text {cloud. }}$.

\section{Data and methods}

The CRF is determined by the difference between all-sky and clear-sky radiative fluxes at the top of the atmosphere. A simple examination of the change in CRF with respect to a temperature change $\left(\frac{\mathrm{dCRF}}{\mathrm{d} T}\right)$ would at first appear to give an estimate of the cloud feedback. However, there are several other climate components that correlate with temperature (surface albedo, water vapor, and the Planck response), which will cause a change in the measured CRF even when no cloud properties have changed (Soden et al., 2008; Shell et al., 2008). Section 2.4 contains details on how the influence of these non-cloud components is removed from the calculated $\Delta \mathrm{CRF}$, yielding $\Delta R_{\text {cloud }}$. Nonetheless, it is clear that the method of determining $\triangle \mathrm{CRF}-$ and, in particular, the

Published by Copernicus Publications on behalf of the European Geosciences Union. 
choice for clear-sky flux - is of primary importance when calculating the cloud feedback in this manner.

\subsection{All-sky radiative fluxes}

For all-sky TOA fluxes (Fig. 1a), we use CERES Single Scanner Footprint (SSF) $1^{\circ}$ global means (CERES SSF1deglite_Ed2.6) (Wielicki et al., 1998; Loeb et al., 2012). We have chosen the CERES SSF1 degree product for consistency with Dessler (2010), and because it is more stable with respect to anomalies than its Energy Balanced and Filled (EBAF) counterpart. This is due to the EBAF product supplementing CERES measurements with those from geostationary satellites, which improves diurnal coverage, but introduces artifacts from the GEO data that can result in spurious jumps or trends in the interannual, deseasonalized anomalies (Loeb et al., 2009).

There are two periods over which we perform the analysis: the Terra period (Table 1), stretching from March 2000 to June 2011, during which time we use the measurements from the CERES instrument aboard the Terra satellite; and the Aqua period (Table 2), from September 2002 to June 2011, during which we average the CERES products coming from the different Terra and Aqua satellites. For each analysis, we calculate anomalies relative to their respective time intervals. We note that the CERES measurements aboard Aqua actually begin in July 2002, but the relevant data from the Atmospheric Infrared Sounder (AIRS) instrument aboard the same satellite are only available beginning in September of that year.

\subsection{Clear-sky radiative fluxes}

We use multiple sources of clear-sky radiative fluxes in order to determine the sensitivity to each choice. A time series of the fluxes from the different data products below can be seen in Figs. $1 b$ and 2.

\subsubsection{CERES clear-sky}

Similar to all-sky fluxes, we use CERES clear-sky fluxes from aboard the Terra satellite over the longer period analysis, and then average the data products during the overlapping Terra and Aqua interval. There are, however, several potential issues with using the CERES clear-sky fluxes to determine the CRF that must be considered. For one, there is a known clear-sky sampling bias for OLR in absolute CERES CRF measurements (Cess and Potter, 1987; Sohn and Bennartz, 2008), as the observations made over areas during clear-sky conditions coincide with less water vapor in that area. The difference between all-sky and clear-sky fluxes thus aliases some of the OLR trapping properties of the water vapor in with the LW CRF. We note here that, if the bias is significant in affecting the changes in $\triangle \mathrm{CRF}$ (rather than simply in the absolute calculation), a rise in temperature would likely lead to increasing water vapor that traps more OLR,
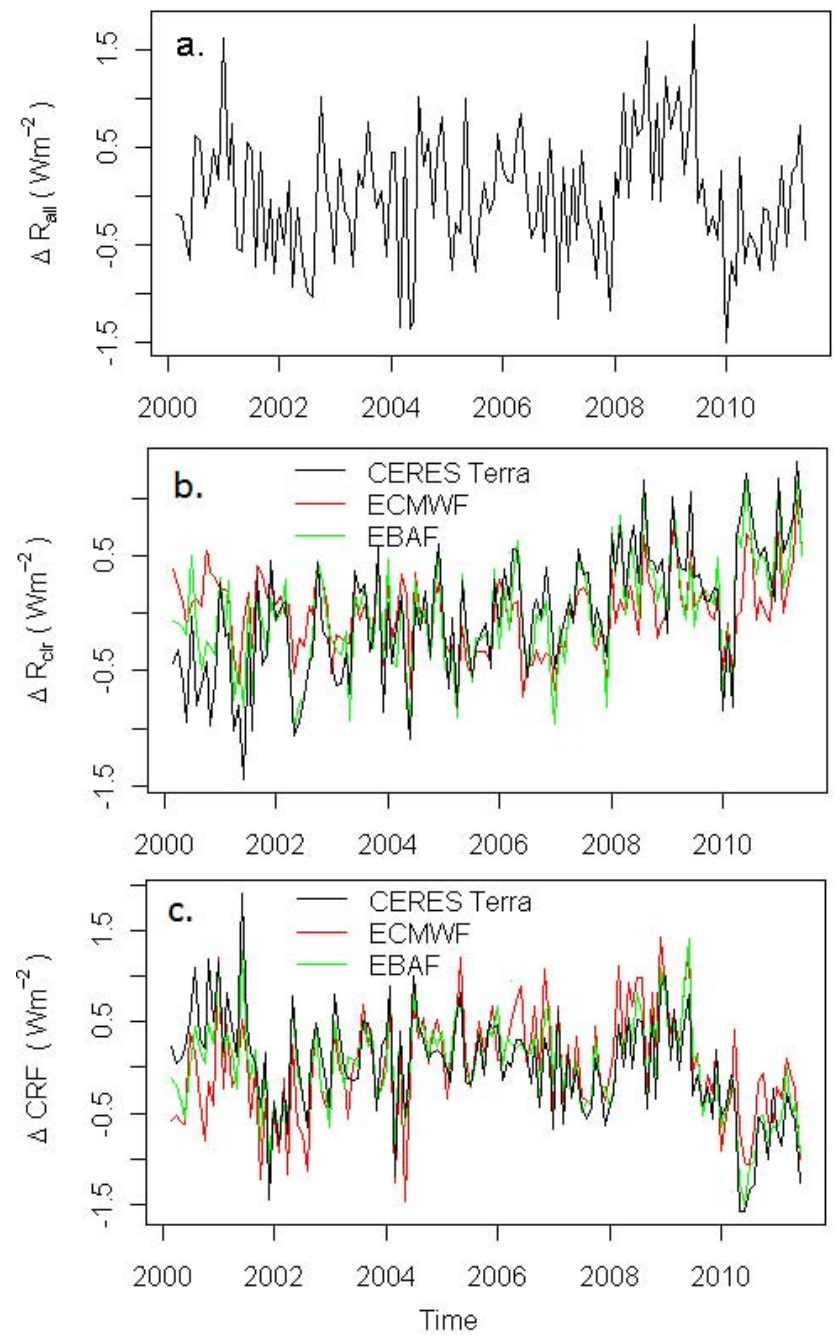

Fig. 1. (a) Global average monthly anomalies for all-sky TOA radiative flux from CERES measurements aboard the Terra satellite. (b) Global average monthly anomalies for clear-sky TOA radiative fluxes from CERES Terra, ECMWF ERA-Interim, and CERES EBAF. (c) The global average monthly CRF anomalies from CERES-only measurements, CERES-ECMWF, and CERES-EBAF.

which will then appear to bias the LW component towards a more positive cloud feedback. However, modeling of this clear-sky sampling bias indicates it has little impact on the interannual anomalies (Allan et al., 2003). Such a bias would be insignificant for the shortwave component, although there may be a similar absolute sampling bias resulting from differences in aerosol concentration between clear-sky and cloudy scenes (Erlick and Ramaswamy, 2003).

Another potential issue with the CERES clear-sky fluxes is the difficulty of the Moderate Resolution Imaging Spectroradiometer (MODIS) instrument in detecting thin cirrus clouds. The MODIS instrument aboard the same satellites (Terra and Aqua) is used to determine whether a scene is 

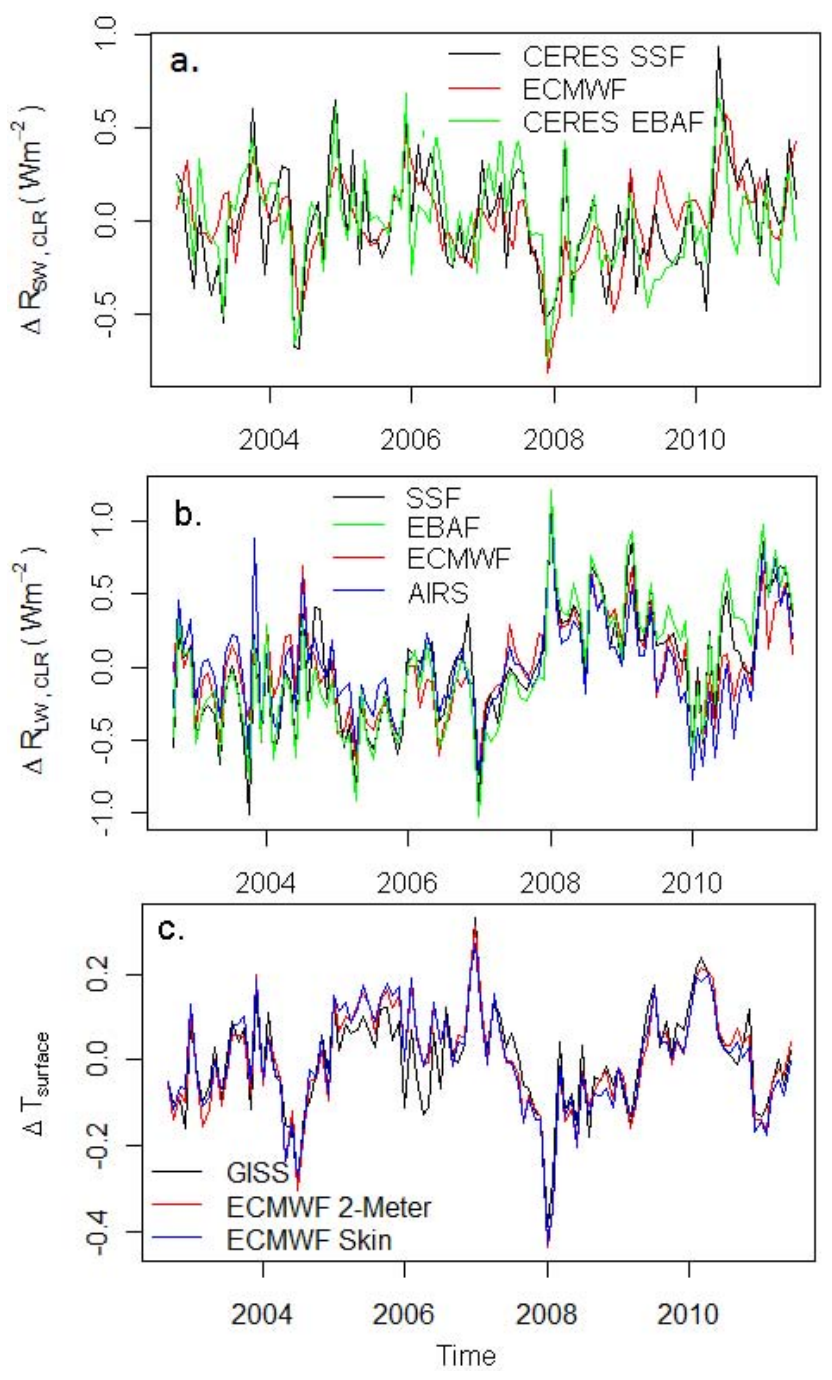

Fig. 2. (a) Global monthly anomalies for shortwave, clear-sky TOA radiative flux from CERES (Terra + Aqua SSF1 degree), ECMWF ERA-Interim, and CERES EBAF. (b) Global monthly anomalies for longwave, clear-sky TOA radiative fluxes from CERES (Terra + Aqua SSF1 degree), ECMWF ERA-Interim, AIRS, and CERES EBAF. (c) Surface temperature anomalies from GISS, ECMWF ERA-Interim 2-m and skin temperatures.

considered clear or cloudy, and misidentification would lead to biases in the reported CERES observations. We note that, although the misidentification is prevalent, with $40 \%$ of tropical scenes considered to be clear-sky containing thin cirrus clouds, the actual radiative effect of these clouds relative to the total CRF in the tropics is small: $\sim 4 \%$ for the SW component (due to their low albedo), and $\sim 10 \%$ for the LW (Lee et al., 2009). Such misidentification may exist near the poles as well, where steep solar zenith angles can exacerbate the difficulties in detecting clouds. The degree to which this would bias the diagnosed feedback in this analysis thus depends on the variability of the thin cirrus cloud types relative to all other clouds types, and the bias for the SW and LW components would be in opposite directions.

The third issue with respect to the CERES clear-sky fluxes is the infrequent sampling of clear-sky scenes over regions that are typically cloudy. The fewer or missing data points over these areas may thus lead to noisier estimates. This is a strong reason for averaging the CERES SSF1 degree Terra and Aqua measurements over their overlapping period, as their different orbits, viewing angles, and cloud conditions for a location can serve to reduce some of the sampling noise. Also, the CERES EBAF clear-sky product uses MODIS narrowband radiances to increase the sampling in these frequently cloudy regions, thereby lowering the sampling uncertainty, although in doing so introduces a narrowto-broadband conversion error. The EBAF clear-sky fluxes have therefore been included in the analysis, along with the SSF1 degree (CERES-only) product.

\subsubsection{AIRS clear-sky}

Additionally, we use the globally averaged, cloud-cleared OLR fluxes from the Atmospheric Infrared Sounder (AIRS) aboard NASA's Aqua satellite (Chahine et al., 2006), available in the AIRX3STM v5 data product. Unfortunately, AIRS clear-sky profiles also have an absolute bias due to undetected thin cirrus clouds (Sun et al., 2011), and are only available during the Aqua period and for the longwave component.

\subsubsection{ECMWF ERA-Interim clear-sky}

Dessler (2010) determined the CRF by subtracting the modeled reanalysis clear-sky fluxes from the CERES measured all-sky fluxes, rather than using the CERES measurements for both the clear-sky and all-sky measurements, specifically to avoid the dry, clear-sky bias discussed above. The sources used by Dessler (2010) for the clear-sky flux were the European Centre for Medium-Range Weather Forecasts (ECMWF) ERA-interim reanalysis (Dee et al., 2011), which we use as a primary source here as well, along with NASA's Modern Era Retrospective analysis for Research and Applications (MERRA) (Rienecker et al., 2011), which we include in the extended sensitivity tests. We note that there are issues with this approach of using reanalysis fluxes as well. First, although the radiative transfer model may accurately derive OLR clear-sky fluxes from temperature and water vapor profiles, the modeling of these temperature and water vapor components themselves is questionable, with spurious water vapor trends noted in current reanalysis (and ERA-Interim in particular) (John et al., 2009). Comparing the kernel-derived effect of AIRS vs. ERAInterim water vapor trends on clear-sky TOA longwave anomalies indicates a difference of $0.07 \mathrm{Wm}^{-2} \mathrm{yr}^{-1}$, and the difference between AIRS and ERA-Interim clear-sky OLR when regressed against temperature is $0.14,-0.04$, 


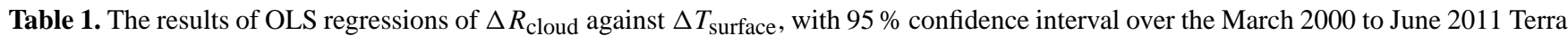
period. Values in parentheses use the unadjusted values of $\triangle \mathrm{CRF}$ in the regressions. All estimates are in $\mathrm{Wm}^{-2} \mathrm{~K}^{-1}$.

\begin{tabular}{|c|c|c|c|c|c|c|c|}
\hline \multirow[t]{2}{*}{$\Delta R_{\text {clear }}$} & \multirow[t]{2}{*}{$\Delta T_{\text {surface }}$} & \multicolumn{3}{|c|}{ Monthly anomalies } & \multicolumn{3}{|c|}{ 3-month anomalies } \\
\hline & & Total & Shortwave & Longwave & Total & Shortwave & Longwave \\
\hline CERES SSF & GISS & $\begin{array}{r}-0.81 \pm 0.71 \\
(-1.06 \pm 0.77)\end{array}$ & $\begin{array}{r}-0.54 \pm 0.76 \\
(-0.72 \pm 0.79)\end{array}$ & $\begin{array}{r}-0.27 \pm 0.45 \\
(-0.34 \pm 0.43)\end{array}$ & $\begin{array}{r}-0.92 \pm 1.08 \\
(-1.35 \pm 1.17)\end{array}$ & $\begin{array}{r}-0.72 \pm 1.12 \\
(-0.95 \pm 1.17)\end{array}$ & $\begin{array}{r}-0.20 \pm 0.68 \\
(-0.40 \pm 0.65)\end{array}$ \\
\hline CERES SSF & $\begin{array}{l}\text { ECMWF } \\
\text { 2-met }\end{array}$ & $\begin{array}{r}-0.60 \pm 0.69 \\
(-0.88 \pm 0.75)\end{array}$ & $\begin{array}{r}-0.57 \pm 0.74 \\
(-0.78 \pm 0.77)\end{array}$ & $\begin{array}{r}-0.03 \pm 0.44 \\
(-0.10 \pm 0.42)\end{array}$ & $\begin{array}{r}-0.54 \pm 1.05 \\
(-0.96 \pm 1.15)\end{array}$ & $\begin{array}{r}-0.60 \pm 1.07 \\
(-0.86 \pm 1.12)\end{array}$ & $\begin{array}{r}0.07 \pm 0.65 \\
(-0.10 \pm 0.63)\end{array}$ \\
\hline CERES SSF & $\begin{array}{l}\text { ECMWF } \\
\text { skin }\end{array}$ & $\begin{array}{r}-0.31 \pm 0.71 \\
(-0.56 \pm 0.77)\end{array}$ & $\begin{array}{r}-0.31 \pm 0.76 \\
(-0.52 \pm 0.79)\end{array}$ & $\begin{array}{r}0.01 \pm 0.45 \\
(-0.04 \pm 0.43)\end{array}$ & $\begin{array}{r}-0.20 \pm 1.08 \\
(-0.63 \pm 1.19)\end{array}$ & $\begin{array}{r}-0.36 \pm 1.10 \\
(-0.63 \pm 1.15)\end{array}$ & $\begin{array}{r}0.16 \pm 0.66 \\
(0.00 \pm 0.64)\end{array}$ \\
\hline ECMWF & GISS & $\begin{array}{r}0.44 \pm 0.71 \\
(0.18 \pm 0.80)\end{array}$ & $\begin{array}{r}0.32 \pm 0.79 \\
(0.14 \pm 0.84)\end{array}$ & $\begin{array}{r}0.12 \pm 0.42 \\
(0.05 \pm 0.42)\end{array}$ & $\begin{array}{r}0.45 \pm 1.08 \\
(0.01 \pm 1.25)\end{array}$ & $\begin{array}{r}0.16 \pm 1.14 \\
(-0.07 \pm 1.24)\end{array}$ & $\begin{array}{r}0.29 \pm 0.59 \\
(0.08 \pm 0.60)\end{array}$ \\
\hline ECMWF & $\begin{array}{l}\text { ECMWF } \\
\text { 2-met }\end{array}$ & $\begin{array}{r}0.52 \pm 0.68 \\
(0.23 \pm 0.77)\end{array}$ & $\begin{array}{r}0.13 \pm 0.77 \\
(-0.08 \pm 0.82)\end{array}$ & $\begin{array}{r}0.38 \pm 0.40 \\
(0.31 \pm 0.40)\end{array}$ & $\begin{array}{r}0.66 \pm 1.02 \\
(0.24 \pm 1.19)\end{array}$ & $\begin{array}{r}0.12 \pm 1.09 \\
(-0.13 \pm 1.18)\end{array}$ & $\begin{array}{r}0.54 \pm 0.55 \\
(0.37 \pm 0.56)\end{array}$ \\
\hline ECMWF & $\begin{array}{l}\text { ECMWF } \\
\text { skin }\end{array}$ & $\begin{array}{r}0.63 \pm 0.69 \\
(0.38 \pm 0.79)\end{array}$ & $\begin{array}{r}0.25 \pm 0.78 \\
(0.04 \pm 0.83)\end{array}$ & $\begin{array}{r}0.38 \pm 0.41 \\
(0.34 \pm 0.41)\end{array}$ & $\begin{array}{r}0.73 \pm 1.03 \\
(0.31 \pm 1.21)\end{array}$ & $\begin{array}{r}0.16 \pm 1.10 \\
(-0.10 \pm 1.21)\end{array}$ & $\begin{array}{r}0.57 \pm 0.55 \\
(0.41 \pm 0.56)\end{array}$ \\
\hline EBAF & GISS & $\begin{array}{r}-0.13 \pm 0.64 \\
(-0.39 \pm 0.70)\end{array}$ & $\begin{array}{r}-0.18 \pm 0.67 \\
(-0.36 \pm 0.70)\end{array}$ & $\begin{array}{r}0.05 \pm 0.43 \\
(-0.03 \pm 0.41)\end{array}$ & $\begin{array}{r}-0.20 \pm 0.99 \\
(-0.63 \pm 1.10)\end{array}$ & $\begin{array}{r}-0.29 \pm 0.98 \\
(-0.52 \pm 1.04)\end{array}$ & $\begin{array}{r}0.09 \pm 0.67 \\
(-0.11 \pm 0.63)\end{array}$ \\
\hline EBAF & $\begin{array}{l}\text { ECMWF } \\
\text { 2-met }\end{array}$ & $\begin{array}{r}-0.01 \pm 0.62 \\
(-0.29 \pm 0.68)\end{array}$ & $\begin{array}{r}-0.24 \pm 0.65 \\
(-0.45 \pm 0.68)\end{array}$ & $\begin{array}{r}0.23 \pm 0.42 \\
(0.16 \pm 0.40)\end{array}$ & $\begin{array}{r}0.08 \pm 0.94 \\
(-0.34 \pm 1.06)\end{array}$ & $\begin{array}{r}-0.24 \pm 0.94 \\
(-0.49 \pm 0.99)\end{array}$ & $\begin{array}{r}0.32 \pm 0.63 \\
(0.15 \pm 0.60)\end{array}$ \\
\hline EBAF & $\begin{array}{l}\text { ECMWF } \\
\text { skin }\end{array}$ & $\begin{array}{r}0.18 \pm 0.63 \\
(-0.08 \pm 0.70)\end{array}$ & $\begin{array}{r}-0.08 \pm 0.66 \\
(-0.29 \pm 0.69)\end{array}$ & $\begin{array}{r}0.26 \pm 0.42 \\
(0.22 \pm 0.41)\end{array}$ & $\begin{array}{r}0.29 \pm 0.95 \\
(-0.13 \pm 1.08)\end{array}$ & $\begin{array}{r}-0.12 \pm 0.96 \\
(-0.38 \pm 1.01)\end{array}$ & $\begin{array}{r}0.41 \pm 0.63 \\
(0.25 \pm 0.60)\end{array}$ \\
\hline $\begin{array}{l}\text { Dessler } \\
(2010)^{*}\end{array}$ & ECMWF & $\begin{array}{r}0.54 \pm 0.74 \\
(0.25 \pm 0.77)\end{array}$ & $0.12 \pm 0.78$ & $0.43 \pm 0.45$ & N/A & N/A & N/A \\
\hline
\end{tabular}

* Reported results from Dessler (2010) using ECMWF-CERES over the March 2000 through February 2010 period.

and $-0.12 \mathrm{Wm}^{-2} \mathrm{~K}^{-1}$ for GISS (Hansen et al., 2010), ERAInterim 2-meter, and ERA-Interim skin temperatures, respectively. Also, as Dessler (2010) notes, the interannual changes in aerosol forcing affecting the all-sky CERES fluxes are not present in the modeled clear-sky fluxes, adding in another discrepancy. Although there is not necessarily a reason to believe these aerosol effects would correlate with surface temperature anomalies, the low correlation between $\Delta R_{\text {cloud }}$ and

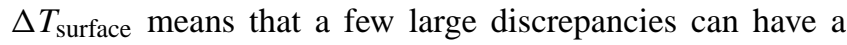
major impact on the estimate.

\subsection{Surface temperature}

For surface temperatures, global anomalies are calculated with respect to the two baseline periods (Terra and Aqua) discussed above. The temperatures sets used in the primary analysis are the GISS land-ocean temperature index (Hansen et al., 2010), ECMWF ERA-Interim 2-m air temperatures (t2m) for consistency with model-estimated feedbacks, and ECMWF ERA-Interim skin temperature (skt) for consistency with Dessler (2010). However, additional sensitivity tests are run using the global temperature anomalies from NCDC (Smith et al., 2008), HadCRUT3 (Brohan et al., 2006), and HadCRUT4 (Jones et al., 2012) (which is currently only available up to December 2010), as well as 2-m air temperatures from the MERRA and NCEP reanalysis products.

\subsection{Removing non-cloud components from $\Delta \mathrm{CRF}$}

The measured $\triangle \mathrm{CRF}$ is influenced by other climate components besides clouds, due to the preferential TOA radiative effect these components have in clear-sky versus cloudy scenes. Generally, the positive surface albedo and water vapor feedbacks will bias towards a negative cloud feedback if these effects are not removed, while the Planck response will create a bias in the opposite (positive) direction, although the magnitude of the net bias is unclear. For comparison with Dessler (2010), we estimate the effect of these non-cloud components by combining the Geophysical Fluid Dynamics Laboratory (GFDL) kernels (Soden et al., 2008) with ECMWF ERA-Interim reanalysis values, as well as the AIRS measured temperature and water vapor profiles where available (during the Aqua period). We also use $0.25 \mathrm{Wm}^{-2}$ to represent the change in well-mixed greenhouse gas (WMGHG) forcing over this period, and 0.16 to represent the degree to which it preferentially affects the OLR in clear-sky vs. all-sky. This is applied by multiplying the factor by each month's WMGHG forcing anomaly relative to the start of the period (linearly increasing), and subtracting the result from $\triangle \mathrm{CRF}$.

One issue of concern is that the spurious trends in the reanalysis data discussed previously may introduce an invalid trend in the cloud feedback due simply to these adjustments. 
Table 2. The results of OLS regressions of $\Delta R_{\text {cloud }}$ against $\Delta T_{\text {surface, }}$, with $95 \%$ confidence interval over the September 2002 to June 2011 Aqua period. Values in parentheses use the unadjusted values of $\Delta \mathrm{CRF}$ in the regressions. All estimates are in $\mathrm{Wm}^{-2} \mathrm{~K}^{-1}$.

\begin{tabular}{|c|c|c|c|c|c|c|c|}
\hline \multirow[t]{2}{*}{$\Delta R_{\text {clear }}$} & \multirow[t]{2}{*}{$\Delta T_{\text {surface }}$} & \multicolumn{3}{|c|}{ Monthly anomalies } & \multicolumn{3}{|c|}{ 3-month anomalies } \\
\hline & & Total & Shortwave & Longwave & Total & Shortwave & Longwave \\
\hline CERES SSF & GISS & $\begin{array}{r}-0.16 \pm 0.81 \\
(-0.36 \pm 0.86)\end{array}$ & $\begin{array}{r}-0.15 \pm 0.78 \\
(-0.42 \pm 0.83)\end{array}$ & $\begin{array}{c}-0.01 \pm 0.62 \\
(0.06 \pm 0.49)\end{array}$ & $\begin{array}{r}0.16 \pm 1.39 \\
(-0.38 \pm 1.47)\end{array}$ & $\begin{array}{r}-0.06 \pm 1.18 \\
(-0.46 \pm 1.28)\end{array}$ & $\begin{array}{r}0.22 \pm 1.03 \\
(0.08 \pm 0.73)\end{array}$ \\
\hline CERES SSF & $\begin{array}{l}\text { ECMWF } \\
\text { 2-met }\end{array}$ & $\begin{array}{r}0.00 \pm 0.75 \\
(-0.31 \pm 0.79)\end{array}$ & $\begin{array}{r}-0.32 \pm 0.72 \\
(-0.60 \pm 0.76)\end{array}$ & $\begin{array}{r}0.31 \pm 0.57 \\
(0.29 \pm 0.45)\end{array}$ & $\begin{array}{r}0.34 \pm 1.24 \\
(-0.18 \pm 1.32)\end{array}$ & $\begin{array}{r}-0.15 \pm 1.06 \\
(-0.52 \pm 1.14)\end{array}$ & $\begin{array}{r}0.49 \pm 0.91 \\
(0.34 \pm 0.64)\end{array}$ \\
\hline CERES SSF & $\begin{array}{l}\text { ECMWF } \\
\text { skin }\end{array}$ & $\begin{array}{r}0.33 \pm 0.75 \\
(0.00 \pm 0.80)\end{array}$ & $\begin{array}{r}-0.11 \pm 0.73 \\
(-0.38 \pm 0.77)\end{array}$ & $\begin{array}{r}0.44 \pm 0.57 \\
(0.38 \pm 0.45)\end{array}$ & $\begin{array}{r}0.69 \pm 1.22 \\
(0.13 \pm 1.32)\end{array}$ & $\begin{array}{r}0.02 \pm 1.06 \\
(-0.32 \pm 1.15)\end{array}$ & $\begin{array}{r}0.66 \pm 0.89 \\
(0.45 \pm 0.63)\end{array}$ \\
\hline ECMWF & GISS & $\begin{array}{r}-0.06 \pm 0.80 \\
(-0.26 \pm 0.88)\end{array}$ & $\begin{array}{r}-0.17 \pm 0.84 \\
(-0.45 \pm 0.90)\end{array}$ & $\begin{array}{r}0.12 \pm 0.57 \\
(0.19 \pm 0.47)\end{array}$ & $\begin{array}{r}0.22 \pm 1.26 \\
(-0.32 \pm 1.45)\end{array}$ & $\begin{array}{r}-0.32 \pm 1.21 \\
(-0.72 \pm 1.32)\end{array}$ & $\begin{array}{r}0.54 \pm 0.87 \\
(0.40 \pm 0.68)\end{array}$ \\
\hline ECMWF & $\begin{array}{l}\text { ECMWF } \\
\text { 2-met }\end{array}$ & $\begin{array}{r}0.22 \pm 0.74 \\
(-0.09 \pm 0.82)\end{array}$ & $\begin{array}{r}-0.35 \pm 0.78 \\
(-0.63 \pm 0.83)\end{array}$ & $\begin{array}{r}0.57 \pm 0.52 \\
(0.54 \pm 0.42)\end{array}$ & $\begin{array}{r}0.60 \pm 1.11 \\
(0.09 \pm 1.30)\end{array}$ & $\begin{array}{r}-0.28 \pm 1.08 \\
(-0.65 \pm 1.19)\end{array}$ & $\begin{array}{r}0.88 \pm 0.73 \\
(0.73 \pm 0.56)\end{array}$ \\
\hline ECMWF & $\begin{array}{l}\text { ECMWF } \\
\text { skin }\end{array}$ & $\begin{array}{r}0.48 \pm 0.74 \\
(0.15 \pm 0.82)\end{array}$ & $\begin{array}{r}-0.16 \pm 0.78 \\
(-0.43 \pm 0.84)\end{array}$ & $\begin{array}{r}0.64 \pm 0.52 \\
(0.58 \pm 0.42)\end{array}$ & $\begin{array}{r}0.83 \pm 1.09 \\
(0.28 \pm 1.30)\end{array}$ & $\begin{array}{r}-0.16 \pm 1.08 \\
(-0.50 \pm 1.19)\end{array}$ & $\begin{array}{r}0.99 \pm 0.71 \\
(0.78 \pm 0.55)\end{array}$ \\
\hline EBAF & GISS & $\begin{array}{r}-0.02 \pm 0.81 \\
(-0.22 \pm 0.85)\end{array}$ & $\begin{array}{r}-0.13 \pm 0.72 \\
(-0.41 \pm 0.74)\end{array}$ & $\begin{array}{r}0.11 \pm 0.63 \\
(0.19 \pm 0.52)\end{array}$ & $\begin{array}{r}0.20 \pm 1.40 \\
(-0.34 \pm 1.49)\end{array}$ & $\begin{array}{r}-0.14 \pm 1.10 \\
(-0.54 \pm 1.14)\end{array}$ & $\begin{array}{r}0.34 \pm 1.10 \\
(0.21 \pm 0.85)\end{array}$ \\
\hline EBAF & $\begin{array}{l}\text { ECMWF } \\
\text { 2-met }\end{array}$ & $\begin{array}{r}0.19 \pm 0.75 \\
(-0.12 \pm 0.79)\end{array}$ & $\begin{array}{r}-0.28 \pm 0.66 \\
(-0.56 \pm 0.68)\end{array}$ & $\begin{array}{r}0.47 \pm 0.58 \\
(0.44 \pm 0.47)\end{array}$ & $\begin{array}{r}0.51 \pm 1.25 \\
(0.00 \pm 1.34)\end{array}$ & $\begin{array}{r}-0.16 \pm 0.99 \\
(-0.53 \pm 1.02)\end{array}$ & $\begin{array}{r}0.67 \pm 0.96 \\
(0.53 \pm 0.74)\end{array}$ \\
\hline EBAF & $\begin{array}{l}\text { ECMWF } \\
\text { skin }\end{array}$ & $\begin{array}{r}0.50 \pm 0.75 \\
(0.17 \pm 0.79)\end{array}$ & $\begin{array}{r}-0.12 \pm 0.67 \\
(-0.39 \pm 0.69)\end{array}$ & $\begin{array}{r}0.62 \pm 0.58 \\
(0.56 \pm 0.47)\end{array}$ & $\begin{array}{r}0.85 \pm 1.22 \\
(0.30 \pm 1.33)\end{array}$ & $\begin{array}{r}-0.03 \pm 0.99 \\
(-0.38 \pm 1.03)\end{array}$ & $\begin{array}{r}0.88 \pm 0.94 \\
(0.67 \pm 0.73)\end{array}$ \\
\hline AIRS & GISS & N/A & N/A & $\begin{array}{r}0.25 \pm 0.58 \\
(0.33 \pm 0.50)\end{array}$ & N/A & N/A & $\begin{array}{r}0.64 \pm 0.84 \\
(0.51 \pm 0.69)\end{array}$ \\
\hline AIRS & $\begin{array}{l}\text { ECMWF } \\
\text { 2-met }\end{array}$ & N/A & N/A & $\begin{array}{r}0.52 \pm 0.53 \\
(0.50 \pm 0.46)\end{array}$ & N/A & N/A & $\begin{array}{r}0.78 \pm 0.73 \\
(0.63 \pm 0.60)\end{array}$ \\
\hline AIRS & $\begin{array}{l}\text { ECMWF } \\
\text { skin }\end{array}$ & N/A & N/A & $\begin{array}{r}0.52 \pm 0.53 \\
(0.46 \pm 0.46)\end{array}$ & N/A & N/A & $\begin{array}{r}0.80 \pm 0.73 \\
(0.59 \pm 0.60)\end{array}$ \\
\hline
\end{tabular}

For an estimate of the potential bias, we compare the estimated cloud feedback using the ERA-Interim reanalysis OLR adjustments vs. AIRS OLR adjustments over the overlapping Aqua period (Fig. 3). The difference (ERAadjusted $R_{\text {cloud }}$ minus AIRS-adjusted $\left.R_{\text {cloud }}\right)$ is $0.17,0.07$, and $0.04 \mathrm{Wm}^{-2} \mathrm{~K}^{-1}$ for GISS, ERA-Interim 2-m, and ERAInterim skin temperature, respectively. As AIRS is not available for the SW component or during the beginning of the Terra period, it is not used for those adjustments and ERAInterim is used instead (Tables 1 and 2).

Another potential issue is that, since GCMs generally do a poor job of reproducing the vertical distribution of clouds (Zhang et al., 2005), the all-sky kernels calculated from such a model may not accurately represent the real-world effect of these non-cloud components on the TOA radiation budget. Additionally, aerosol changes may also produce a noncloud influence on $\triangle \mathrm{CRF}$, whether they result from small volcanic eruptions (Solomon et al., 2011) or are of anthropogenic origin (Kaufmann et al., 2011), although significant influence on the apparent cloud feedback is questionable, because, as discussed previously, these aerosol variations are not expected to correlate with the monthly surface

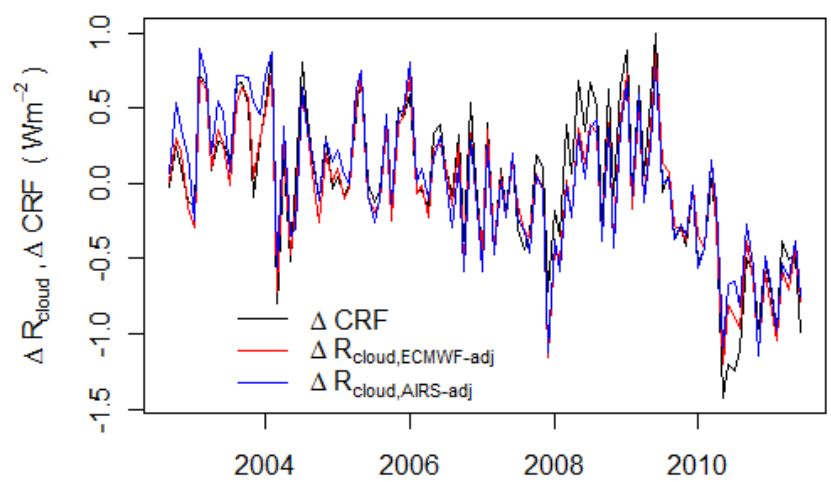

Fig. 3. Global monthly anomalies for the cloud radiative forcing from CERES SSF without adjustments ( $\triangle \mathrm{CRF}$ ), and with adjustments using ECMWF ( $\left.\Delta R_{\text {cloud,ECMWF-adj }}\right)$ or AIRS ( $\Delta R_{\text {cloud,AIRS-adj }}$ ) for water vapor, temperature, and WMGHG contributions. Both versions of $\Delta R_{\text {cloud }}$ use ECMWF albedo for adjustments. 
temperature variations. Nonetheless, for these reasons we also present our regressions of the unadjusted $\triangle \mathrm{CRF}$ against surface temperature (Tables 1 and 2).

\section{Results}

Tables 1 and 2 show the results of the OLS (ordinary least squares) regressions, with uncertainties presented for the $2.5 \%$ to $97.5 \%$ confidence interval as a result of those regressions (no explicit uncertainty calculations have been made for uncertainty in forcings or measurements). The $r^{2}$ values for these $\Delta R_{\text {cloud }}$ versus $\Delta T_{\text {surface }}$ regressions using monthly anomalies and CERES-only derived $\triangle \mathrm{CRF}$ during the Terra period are $3.7 \%, 2.1 \%$, and $0.5 \%$ for GISS, ECMWF 2-m and skin temperatures, respectively, with $1.1 \%, 1.6 \%$, and $2.4 \%$ for CERES-ECMWF using the same temperature sets. It is during this time period that the larger sensitivity to clear-sky flux data exists, with the CERES SSF estimate generally suggesting a modest to large negative cloud feedback, whereas the CERES-ECMWF estimate implies a modest positive cloud feedback, with CERESEBAF falling in the middle. Table 3 shows that the sensitivity to clear-sky flux source extends even to the reanalyses products, with the difference between MERRA and ERAInterim estimates ranging from 0.45 to $-0.04 \mathrm{Wm}^{-2} \mathrm{~K}^{-1}$, and MERRA generally producing the more positive estimate of the cloud feedback.

The sensitivity of these regressions to the start date can be seen in Fig. 4. During the Aqua period, there is better agreement among the ECMWF, CERES (both SSF and EBAF), and AIRS modeled clear sky estimates, with either a slightly negative or positive net cloud feedback implied, but this period shows a large sensitivity to the choice of temperature dataset. Table 4 highlights this sensitivity with seven different temperature datasets. Using MERRA or HadCRUT3 temperatures produces very large positive estimates for the cloud feedback, although the newer HadCRUT4 results in more negative estimates better in line with GISS and NCEP. There is less sensitivity of the sign over this period for the separate shortwave and longwave components, with most results showing a negative shortwave feedback and a positive longwave feedback, although again using the MERRA reanalysis produces an exception.

The effect of the kernel adjustments can also be seen in these tables. According to the AIRS observations used for these adjustments over the Aqua period, the net combination of the water vapor, Planck, and WMGHG components leads only to tiny negative or even positive bias in the unadjusted $\triangle \mathrm{CRF}$ regressions. This is different from the long-term effect of these non-cloud components in models, which create a larger negative bias in the unadjusted $\triangle \mathrm{CRF}$, but likely results here from the better month-to-month correlation between the Planck response and $\Delta T_{\text {surface }}$ than between water vapor anomalies and $\Delta T_{\text {surface }}$.

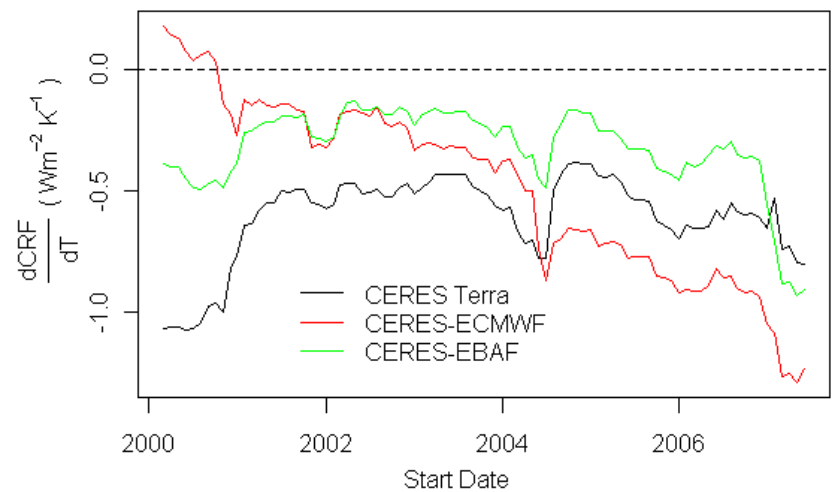

Fig. 4. The sensitivity of $\frac{\mathrm{dCRF}}{\mathrm{d} T}$ to different start dates (all regressions end in June 2011), showing all regressions four years or longer. GISS is used for $\Delta T_{\text {surface }}$.

The results also suggest that there is not much to be gained by using seasonal rather than monthly anomalies in this analysis, as the uncertainty bounds only increase due to the fewer available observations, while failing to illuminate a strong signal absent in the monthly anomalies.

\section{Discussion}

Overall, the results show that estimates for the net short-term feedback using this methodology are sensitive to temperature datasets, the time period for which we run the regressions, and the choice of clear-sky radiation fluxes. The large uncertainties and sensitivities make it difficult to deem the GCM positive cloud feedbacks inconsistent with observations. Similarly, the uncertainty makes it difficult to rule out the possibility of a large negative cloud feedback. However, over the Aqua period, the majority of datasets point to a negative feedback in the SW component, in contrast to a positive feedback in the LW component. These results tend to be opposite of those found in Zelinka and Hartmann (2011), who examined only the tropical means and found a negative LW feedback counteracted by a positive SW cloud feedback, with a net positive feedback. Davies and Molloy (2012) used a different method, examining the 10 -yr negative trend in cloud height as retrieved from the Multiangle Imaging SpectroRadiometer (MISR) aboard Terra, in order to infer a potential negative LW cloud feedback.

Due to the low correlations between global surface temperature and $\triangle \mathrm{CRF}$, it is clear that the variations in the cloud forcing are resulting from other changes in the climatology, and that clouds are acting as more than simple feedbacks on these timescales. This variation may result from a separate fast response to aerosol forcing (Andrews et al., 2010), from tropical intraseasonal oscillations (Spencer et al., 2007), or from other sources of natural variability. To the degree that this radiative noise from cloud fluctuations influences surface temperatures within a lag time shorter than the decorrelation 
Table 3. Extended sensitivity tests. As in Table 1, but with additional temperature and clear-sky flux datasets, and only using monthly anomalies.

\begin{tabular}{|c|c|c|c|c|}
\hline$\Delta R_{\text {clear }}$ & $\Delta T_{\text {surface }}$ & Total & Shortwave & Longwave \\
\hline CERES SSF & GISS & $\begin{array}{r}-0.81 \pm 0.71 \\
(-1.06 \pm 0.77)\end{array}$ & $\begin{array}{r}-0.54 \pm 0.76 \\
(-0.72 \pm 0.79)\end{array}$ & $\begin{array}{r}-0.27 \pm 0.45 \\
(-0.34 \pm 0.43)\end{array}$ \\
\hline ECMWF & GISS & $\begin{array}{r}0.44 \pm 0.71 \\
(0.18 \pm 0.80)\end{array}$ & $\begin{array}{r}0.32 \pm 0.79 \\
(0.14 \pm 0.84)\end{array}$ & $\begin{array}{r}0.12 \pm 0.42 \\
(0.05 \pm 0.42)\end{array}$ \\
\hline EBAF & GISS & $\begin{array}{r}-0.13 \pm 0.64 \\
(-0.39 \pm 0.70)\end{array}$ & $\begin{array}{r}-0.18 \pm 0.67 \\
(-0.36 \pm 0.70)\end{array}$ & $\begin{array}{r}0.05 \pm 0.43 \\
(-0.03 \pm 0.41)\end{array}$ \\
\hline MERRA & GISS & $\begin{array}{r}0.86 \pm 0.70 \\
(0.60 \pm 0.77)\end{array}$ & $\begin{array}{r}0.48 \pm 0.71 \\
(0.30 \pm 0.74)\end{array}$ & $\begin{array}{r}0.38 \pm 0.42 \\
(0.30 \pm 0.41)\end{array}$ \\
\hline CERES SSF & NCDC & $\begin{array}{r}-0.77 \pm 0.86 \\
(-1.02 \pm 0.93)\end{array}$ & $\begin{array}{r}-0.62 \pm 0.92 \\
(-0.78 \pm 0.96)\end{array}$ & $\begin{array}{r}-0.16 \pm 0.54 \\
(-0.24 \pm 0.53)\end{array}$ \\
\hline ECMWF & NCDC & $\begin{array}{r}0.43 \pm 0.85 \\
(0.18 \pm 0.96)\end{array}$ & $\begin{array}{r}0.39 \pm 0.95 \\
(0.23 \pm 1.01)\end{array}$ & $\begin{array}{r}0.04 \pm 0.50 \\
(-0.05 \pm 0.50)\end{array}$ \\
\hline EBAF & $\mathrm{NCDC}$ & $\begin{array}{r}-0.12 \pm 0.77 \\
(-0.37 \pm 0.85)\end{array}$ & $\begin{array}{r}-0.31 \pm 0.81 \\
(-0.47 \pm 0.84)\end{array}$ & $\begin{array}{r}0.19 \pm 0.52 \\
(0.10 \pm 0.50)\end{array}$ \\
\hline MERRA & NCDC & $\begin{array}{r}0.79 \pm 0.85 \\
(0.54 \pm 0.94)\end{array}$ & $\begin{array}{r}0.44 \pm 0.85 \\
(0.28 \pm 0.90)\end{array}$ & $\begin{array}{r}0.35 \pm 0.50 \\
(0.26 \pm 0.50)\end{array}$ \\
\hline CERES SSF & HadCRUT3 & $\begin{array}{r}-0.27 \pm 0.93 \\
(-0.69 \pm 1.01)\end{array}$ & $\begin{array}{r}-0.42 \pm 0.99 \\
(-0.66 \pm 1.02)\end{array}$ & $\begin{array}{r}0.15 \pm 0.58 \\
(-0.03 \pm 0.56)\end{array}$ \\
\hline ECMWF & HadCRUT3 & $\begin{array}{r}0.54 \pm 0.91 \\
(0.13 \pm 1.03)\end{array}$ & $\begin{array}{r}0.25 \pm 1.02 \\
(0.01 \pm 1.08)\end{array}$ & $\begin{array}{r}0.30 \pm 0.53 \\
(0.12 \pm 0.53)\end{array}$ \\
\hline EBAF & HadCRUT3 & $\begin{array}{r}0.33 \pm 0.82 \\
(-0.09 \pm 0.91)\end{array}$ & $\begin{array}{r}-0.23 \pm 0.86 \\
(-0.47 \pm 0.90)\end{array}$ & $\begin{array}{r}0.56 \pm 0.55 \\
(0.38 \pm 0.53)\end{array}$ \\
\hline MERRA & HadCRUT3 & $\begin{array}{r}0.98 \pm 0.90 \\
(0.56 \pm 1.00)\end{array}$ & $\begin{array}{r}0.47 \pm 0.91 \\
(0.23 \pm 0.96)\end{array}$ & $\begin{array}{r}0.51 \pm 0.54 \\
(0.33 \pm 0.53)\end{array}$ \\
\hline CERES SSF & HadCRUT4* & $\begin{array}{r}-0.96 \pm 0.81 \\
(-1.25 \pm 0.88)\end{array}$ & $\begin{array}{r}-0.71 \pm 0.89 \\
(-0.93 \pm 0.92)\end{array}$ & $\begin{array}{r}-0.25 \pm 0.51 \\
(-0.32 \pm 0.50)\end{array}$ \\
\hline ECMWF & HadCRUT4* & $\begin{array}{r}0.54 \pm 0.84 \\
(0.25 \pm 0.95)\end{array}$ & $\begin{array}{r}0.37 \pm 0.93 \\
(0.14 \pm 0.98)\end{array}$ & $\begin{array}{r}0.17 \pm 0.48 \\
(0.11 \pm 0.49)\end{array}$ \\
\hline EBAF & HadCRUT4* & $\begin{array}{r}-0.10 \pm 0.74 \\
(-0.39 \pm 0.82)\end{array}$ & $\begin{array}{r}-0.21 \pm 0.78 \\
(-0.43 \pm 0.82)\end{array}$ & $\begin{array}{r}0.10 \pm 0.48 \\
(0.04 \pm 0.47)\end{array}$ \\
\hline MERRA & HadCRUT4* & $\begin{array}{r}0.99 \pm 0.84 \\
(0.70 \pm 0.93)\end{array}$ & $\begin{array}{r}0.50 \pm 0.84 \\
(0.27 \pm 0.88)\end{array}$ & $\begin{array}{r}0.49 \pm 0.48 \\
(0.42 \pm 0.48)\end{array}$ \\
\hline CERES SSF & ECMWF $\mathrm{t} 2 \mathrm{~m}$ & $\begin{array}{r}-0.60 \pm 0.69 \\
(-0.88 \pm 0.75)\end{array}$ & $\begin{array}{r}-0.57 \pm 0.74 \\
(-0.78 \pm 0.77)\end{array}$ & $\begin{array}{r}-0.03 \pm 0.44 \\
(-0.10 \pm 0.42)\end{array}$ \\
\hline ECMWF & ECMWF t2m & $\begin{array}{r}0.52 \pm 0.68 \\
(0.23 \pm 0.77)\end{array}$ & $\begin{array}{r}0.13 \pm 0.77 \\
(-0.08 \pm 0.82)\end{array}$ & $\begin{array}{r}0.38 \pm 0.40 \\
(0.31 \pm 0.40)\end{array}$ \\
\hline EBAF & ECMWF $\mathrm{t} 2 \mathrm{~m}$ & $\begin{array}{r}-0.01 \pm 0.62 \\
(-0.29 \pm 0.68)\end{array}$ & $\begin{array}{r}-0.24 \pm 0.65 \\
(-0.45 \pm 0.68)\end{array}$ & $\begin{array}{r}0.23 \pm 0.42 \\
(0.16 \pm 0.40)\end{array}$ \\
\hline MERRA & ECMWF t2m & $\begin{array}{r}0.72 \pm 0.68 \\
(0.44 \pm 0.75)\end{array}$ & $\begin{array}{r}0.25 \pm 0.69 \\
(0.04 \pm 0.72)\end{array}$ & $\begin{array}{r}0.47 \pm 0.40 \\
(0.40 \pm 0.40)\end{array}$ \\
\hline CERES SSF & MERRA $\mathrm{t} 2 \mathrm{~m}$ & $\begin{array}{r}0.00 \pm 0.74 \\
(-0.20 \pm 0.80)\end{array}$ & $\begin{array}{r}-0.16 \pm 0.78 \\
(-0.29 \pm 0.82)\end{array}$ & $\begin{array}{r}0.16 \pm 0.46 \\
(0.08 \pm 0.45)\end{array}$ \\
\hline ECMWF & MERRA $\mathrm{t} 2 \mathrm{~m}$ & $\begin{array}{r}0.65 \pm 0.72 \\
(0.45 \pm 0.81)\end{array}$ & $\begin{array}{r}0.48 \pm 0.80 \\
(0.35 \pm 0.85)\end{array}$ & $\begin{array}{r}0.17 \pm 0.42 \\
(0.10 \pm 0.42)\end{array}$ \\
\hline EBAF & MERRA $\mathrm{t} 2 \mathrm{~m}$ & $\begin{array}{r}0.41 \pm 0.65 \\
(0.20 \pm 0.72)\end{array}$ & $\begin{array}{r}-0.08 \pm 0.69 \\
(-0.21 \pm 0.72)\end{array}$ & $\begin{array}{r}0.49 \pm 0.43 \\
(0.42 \pm 0.42)\end{array}$ \\
\hline MERRA & MERRA $\mathrm{t} 2 \mathrm{~m}$ & $\begin{array}{r}0.62 \pm 0.72 \\
(0.41 \pm 0.79)\end{array}$ & $\begin{array}{r}0.36 \pm 0.72 \\
(0.23 \pm 0.76)\end{array}$ & $\begin{array}{r}0.25 \pm 0.43 \\
(0.18 \pm 0.42)\end{array}$ \\
\hline CERES SSF & NCEP $\mathrm{t} 2 \mathrm{~m}$ & $\begin{array}{r}-0.77 \pm 0.61 \\
(-0.97 \pm 0.65)\end{array}$ & $\begin{array}{r}-0.56 \pm 0.65 \\
(-0.68 \pm 0.68)\end{array}$ & $\begin{array}{r}-0.21 \pm 0.39 \\
(-0.30 \pm 0.37)\end{array}$ \\
\hline ECMWF & NCEP $\mathrm{t} 2 \mathrm{~m}$ & $\begin{array}{r}0.59 \pm 0.60 \\
(0.39 \pm 0.68)\end{array}$ & $\begin{array}{r}0.38 \pm 0.67 \\
(0.26 \pm 0.72)\end{array}$ & $\begin{array}{r}0.21 \pm 0.35 \\
(0.13 \pm 0.36)\end{array}$ \\
\hline EBAF & NCEP $\mathrm{t} 2 \mathrm{~m}$ & $\begin{array}{r}-0.07 \pm 0.55 \\
(-0.28 \pm 0.60)\end{array}$ & $\begin{array}{r}-0.17 \pm 0.58 \\
(-0.29 \pm 0.60)\end{array}$ & $\begin{array}{r}0.10 \pm 0.37 \\
(0.01 \pm 0.35)\end{array}$ \\
\hline MERRA & NCEP $\mathrm{t} 2 \mathrm{~m}$ & $\begin{array}{r}0.93 \pm 0.59 \\
(0.73 \pm 0.66)\end{array}$ & $\begin{array}{r}0.39 \pm 0.61 \\
(0.28 \pm 0.64)\end{array}$ & $\begin{array}{r}0.54 \pm 0.35 \\
(0.45 \pm 0.35)\end{array}$ \\
\hline
\end{tabular}

* HadCRUT4 is only available up to December 2010 . 
Table 4. Extended sensitivity tests. As in Table 2, but with additional temperature and clear-sky flux datasets, and only using monthly anomalies.

\begin{tabular}{|c|c|c|c|c|}
\hline$\Delta R_{\text {clear }}$ & $\Delta T_{\text {surface }}$ & Total & Shortwave & Longwave \\
\hline Terra & GISS & $\begin{array}{r}-0.36 \pm 0.86 \\
(-0.56 \pm 0.88)\end{array}$ & $\begin{array}{r}-0.21 \pm 0.80 \\
(-0.49 \pm 0.84)\end{array}$ & $\begin{array}{r}-0.15 \pm 0.64 \\
(-0.08 \pm 0.52)\end{array}$ \\
\hline Aqua & GISS & $\begin{array}{r}0.04 \pm 0.83 \\
(-0.16 \pm 0.89)\end{array}$ & $\begin{array}{r}-0.08 \pm 0.79 \\
(-0.36 \pm 0.84)\end{array}$ & $\begin{array}{r}0.12 \pm 0.64 \\
(0.20 \pm 0.52)\end{array}$ \\
\hline SSF AVG & GISS & $\begin{array}{r}-0.16 \pm 0.81 \\
(-0.36 \pm 0.86)\end{array}$ & $\begin{array}{r}-0.15 \pm 0.78 \\
(-0.42 \pm 0.83)\end{array}$ & $\begin{array}{r}-0.01 \pm 0.62 \\
(0.06 \pm 0.49)\end{array}$ \\
\hline ECMWF & GISS & $\begin{array}{r}-0.06 \pm 0.80 \\
(-0.26 \pm 0.88)\end{array}$ & $\begin{array}{r}-0.17 \pm 0.84 \\
(-0.45 \pm 0.90)\end{array}$ & $\begin{array}{r}0.12 \pm 0.57 \\
(0.19 \pm 0.47)\end{array}$ \\
\hline EBAF & GISS & $\begin{array}{r}-0.02 \pm 0.81 \\
(-0.22 \pm 0.85)\end{array}$ & $\begin{array}{r}-0.13 \pm 0.72 \\
(-0.41 \pm 0.74)\end{array}$ & $\begin{array}{r}0.11 \pm 0.63 \\
(0.19 \pm 0.52)\end{array}$ \\
\hline MERRA & GISS & $\begin{array}{r}0.21 \pm 0.73 \\
(0.01 \pm 0.78)\end{array}$ & $\begin{array}{r}0.21 \pm 0.74 \\
(-0.07 \pm 0.77)\end{array}$ & $\begin{array}{r}0.00 \pm 0.53 \\
(0.08 \pm 0.45)\end{array}$ \\
\hline AIRS & GISS & N/A & N/A & $\begin{array}{r}0.25 \pm 0.58 \\
(0.33 \pm 0.50)\end{array}$ \\
\hline Terra & $\mathrm{NCDC}$ & $\begin{array}{r}0.15 \pm 1.05 \\
(-0.15 \pm 1.08)\end{array}$ & $\begin{array}{r}-0.16 \pm 0.97 \\
(-0.39 \pm 1.03)\end{array}$ & $\begin{array}{r}0.31 \pm 0.78 \\
(0.24 \pm 0.64)\end{array}$ \\
\hline Aqua & $\mathrm{NCDC}$ & $\begin{array}{r}0.43 \pm 1.00 \\
(0.13 \pm 1.09)\end{array}$ & $\begin{array}{r}-0.11 \pm 0.96 \\
(-0.34 \pm 1.02)\end{array}$ & $\begin{array}{r}0.54 \pm 0.77 \\
(0.47 \pm 0.63)\end{array}$ \\
\hline SSF AVG & $\mathrm{NCDC}$ & $\begin{array}{r}0.29 \pm 0.99 \\
(-0.01 \pm 1.05)\end{array}$ & $\begin{array}{r}-0.13 \pm 0.95 \\
(-0.36 \pm 1.01)\end{array}$ & $\begin{array}{r}0.43 \pm 0.74 \\
(0.35 \pm 0.59)\end{array}$ \\
\hline ECMWF & NCDC & $\begin{array}{r}0.20 \pm 0.97 \\
(-0.10 \pm 1.08)\end{array}$ & $\begin{array}{r}-0.11 \pm 1.03 \\
(-0.34 \pm 1.10)\end{array}$ & $\begin{array}{r}0.31 \pm 0.70 \\
(0.24 \pm 0.57)\end{array}$ \\
\hline EBAF & $\mathrm{NCDC}$ & $\begin{array}{r}0.32 \pm 0.98 \\
(0.02 \pm 1.03)\end{array}$ & $\begin{array}{r}-0.24 \pm 0.87 \\
(-0.47 \pm 0.90)\end{array}$ & $\begin{array}{r}0.56 \pm 0.76 \\
(0.49 \pm 0.62)\end{array}$ \\
\hline MERRA & $\mathrm{NCDC}$ & $\begin{array}{r}0.34 \pm 0.89 \\
(0.03 \pm 0.95)\end{array}$ & $\begin{array}{r}0.12 \pm 0.90 \\
(-0.11 \pm 0.93)\end{array}$ & $\begin{array}{r}0.22 \pm 0.64 \\
(0.14 \pm 0.55)\end{array}$ \\
\hline AIRS & $\mathrm{NCDC}$ & N/A & N/A & $\begin{array}{r}0.51 \pm 0.70 \\
(0.44 \pm 0.61)\end{array}$ \\
\hline Terra & HadCRUT3 & $\begin{array}{r}1.10 \pm 1.09 \\
(0.43 \pm 1.14)\end{array}$ & $\begin{array}{r}0.16 \pm 1.03 \\
(-0.11 \pm 1.09)\end{array}$ & $\begin{array}{r}0.94 \pm 0.81 \\
(0.53 \pm 0.66)\end{array}$ \\
\hline Aqua & HadCRUT3 & $\begin{array}{r}1.05 \pm 1.04 \\
(0.37 \pm 1.15)\end{array}$ & $\begin{array}{r}-0.10 \pm 1.01 \\
(-0.36 \pm 1.08)\end{array}$ & $\begin{array}{r}1.14 \pm 0.79 \\
(0.74 \pm 0.65)\end{array}$ \\
\hline SSF AVG & HadCRUT3 & $\begin{array}{r}1.07 \pm 1.02 \\
(0.40 \pm 1.10)\end{array}$ & $\begin{array}{r}0.03 \pm 1.00 \\
(-0.24 \pm 1.06)\end{array}$ & $\begin{array}{r}1.04 \pm 0.76 \\
(0.63 \pm 0.61)\end{array}$ \\
\hline ECMWF & HadCRUT3 & $\begin{array}{r}0.72 \pm 1.02 \\
(0.05 \pm 1.14)\end{array}$ & $\begin{array}{r}-0.15 \pm 1.08 \\
(-0.42 \pm 1.16)\end{array}$ & $\begin{array}{r}0.87 \pm 0.72 \\
(0.47 \pm 0.59)\end{array}$ \\
\hline EBAF & HadCRUT3 & $\begin{array}{r}1.15 \pm 1.01 \\
(0.48 \pm 1.09)\end{array}$ & $\begin{array}{r}-0.04 \pm 0.92 \\
(-0.31 \pm 0.96)\end{array}$ & $\begin{array}{r}1.20 \pm 0.78 \\
(0.79 \pm 0.64)\end{array}$ \\
\hline MERRA & HadCRUT3 & $\begin{array}{r}1.02 \pm 0.92 \\
(0.34 \pm 1.00)\end{array}$ & $\begin{array}{r}0.31 \pm 0.95 \\
(0.04 \pm 0.99)\end{array}$ & $\begin{array}{r}0.71 \pm 0.66 \\
(0.31 \pm 0.58)\end{array}$ \\
\hline AIRS & HadCRUT3 & N/A & N/A & $\begin{array}{r}1.03 \pm 0.72 \\
(0.63 \pm 0.64)\end{array}$ \\
\hline Terra & HadCRUT4* & $\begin{array}{r}-0.30 \pm 1.02 \\
(-0.67 \pm 1.04)\end{array}$ & $\begin{array}{r}-0.26 \pm 0.97 \\
(-0.62 \pm 1.01)\end{array}$ & $\begin{array}{r}-0.04 \pm 0.75 \\
(-0.05 \pm 0.61)\end{array}$ \\
\hline Aqua & HadCRUT4* & $\begin{array}{r}0.15 \pm 0.96 \\
(-0.22 \pm 1.05)\end{array}$ & $\begin{array}{r}-0.13 \pm 0.95 \\
(-0.49 \pm 1.00)\end{array}$ & $\begin{array}{r}0.28 \pm 0.74 \\
(0.28 \pm 0.60)\end{array}$ \\
\hline SSF AVG & HadCRUT4* & $\begin{array}{r}-0.07 \pm 0.95 \\
(-0.45 \pm 1.00)\end{array}$ & $\begin{array}{r}-0.19 \pm 0.94 \\
(-0.56 \pm 0.99)\end{array}$ & $\begin{array}{r}0.12 \pm 0.71 \\
(0.11 \pm 0.56)\end{array}$ \\
\hline
\end{tabular}


Table 4. Continued.

\begin{tabular}{|c|c|c|c|c|}
\hline$\Delta R_{\text {clear }}$ & $\Delta T_{\text {surface }}$ & Total & Shortwave & Longwave \\
\hline ECMWF & HadCRUT4* & $\begin{array}{r}0.20 \pm 0.98 \\
(-0.17 \pm 1.08)\end{array}$ & $\begin{array}{r}-0.10 \pm 1.02 \\
(-0.47 \pm 1.08)\end{array}$ & $\begin{array}{r}0.30 \pm 0.68 \\
(0.30 \pm 0.56)\end{array}$ \\
\hline EBAF & HadCRUT4* & $\begin{array}{r}0.15 \pm 0.97 \\
(-0.22 \pm 1.02)\end{array}$ & $\begin{array}{r}-0.05 \pm 0.86 \\
(-0.41 \pm 0.89)\end{array}$ & $\begin{array}{r}0.20 \pm 0.72 \\
(0.19 \pm 0.59)\end{array}$ \\
\hline MERRA & HadCRUT4* & $\begin{array}{r}0.48 \pm 0.91 \\
(0.11 \pm 0.97)\end{array}$ & $\begin{array}{r}0.30 \pm 0.91 \\
(-0.06 \pm 0.94)\end{array}$ & $\begin{array}{r}0.18 \pm 0.63 \\
(0.17 \pm 0.54)\end{array}$ \\
\hline AIRS & HadCRUT4* & N/A & N/A & $\begin{array}{r}0.35 \pm 0.66 \\
(0.34 \pm 0.58)\end{array}$ \\
\hline Terra & ECMWF t2m & $\begin{array}{r}-0.08 \pm 0.80 \\
(-0.39 \pm 0.82)\end{array}$ & $\begin{array}{r}-0.35 \pm 0.74 \\
(-0.64 \pm 0.77)\end{array}$ & $\begin{array}{r}0.27 \pm 0.59 \\
(0.24 \pm 0.48)\end{array}$ \\
\hline Aqua & ECMWF t2m & $\begin{array}{r}0.08 \pm 0.76 \\
(-0.24 \pm 0.83)\end{array}$ & $\begin{array}{r}-0.28 \pm 0.73 \\
(-0.57 \pm 0.77)\end{array}$ & $\begin{array}{r}0.36 \pm 0.59 \\
(0.33 \pm 0.48)\end{array}$ \\
\hline SSF AVG & ECMWF t2m & $\begin{array}{r}0.00 \pm 0.75 \\
(-0.31 \pm 0.79)\end{array}$ & $\begin{array}{r}-0.32 \pm 0.72 \\
(-0.60 \pm 0.76)\end{array}$ & $\begin{array}{r}0.31 \pm 0.57 \\
(0.29 \pm 0.45)\end{array}$ \\
\hline ECMWF & ECMWF t2m & $\begin{array}{r}0.22 \pm 0.74 \\
(-0.09 \pm 0.82)\end{array}$ & $\begin{array}{r}-0.35 \pm 0.78 \\
(-0.63 \pm 0.83)\end{array}$ & $\begin{array}{r}0.57 \pm 0.52 \\
(0.54 \pm 0.42)\end{array}$ \\
\hline EBAF & ECMWF t $2 m$ & $\begin{array}{r}0.19 \pm 0.75 \\
(-0.12 \pm 0.79)\end{array}$ & $\begin{array}{r}-0.28 \pm 0.66 \\
(-0.56 \pm 0.68)\end{array}$ & $\begin{array}{r}0.47 \pm 0.58 \\
(0.44 \pm 0.47)\end{array}$ \\
\hline MERRA & ECMWF t $2 \mathrm{~m}$ & $\begin{array}{r}0.24 \pm 0.68 \\
(-0.08 \pm 0.72)\end{array}$ & $\begin{array}{r}-0.08 \pm 0.68 \\
(-0.36 \pm 0.71)\end{array}$ & $\begin{array}{r}0.31 \pm 0.49 \\
(0.29 \pm 0.41)\end{array}$ \\
\hline AIRS & ECMWF t $2 \mathrm{~m}$ & N/A & N/A & $\begin{array}{r}0.52 \pm 0.53 \\
(0.50 \pm 0.46)\end{array}$ \\
\hline Terra & MERRA $\mathrm{t} 2 \mathrm{~m}$ & $\begin{array}{r}1.04 \pm 0.83 \\
(0.76 \pm 0.87)\end{array}$ & $\begin{array}{r}0.20 \pm 0.79 \\
(0.07 \pm 0.84)\end{array}$ & $\begin{array}{r}0.84 \pm 0.62 \\
(0.69 \pm 0.50)\end{array}$ \\
\hline Aqua & MERRA t $2 \mathrm{~m}$ & $\begin{array}{r}0.94 \pm 0.80 \\
(0.67 \pm 0.88)\end{array}$ & $\begin{array}{r}0.16 \pm 0.78 \\
(0.03 \pm 0.84)\end{array}$ & $\begin{array}{r}0.79 \pm 0.62 \\
(0.64 \pm 0.50)\end{array}$ \\
\hline SSF AVG & MERRA $\mathrm{t} 2 \mathrm{~m}$ & $\begin{array}{r}0.99 \pm 0.78 \\
(0.72 \pm 0.84)\end{array}$ & $\begin{array}{r}0.18 \pm 0.77 \\
(0.05 \pm 0.82)\end{array}$ & $\begin{array}{r}0.82 \pm 0.59 \\
(0.67 \pm 0.47)\end{array}$ \\
\hline ECMWF & MERRA t $2 \mathrm{~m}$ & $\begin{array}{r}0.76 \pm 0.78 \\
(0.48 \pm 0.88)\end{array}$ & $\begin{array}{r}0.12 \pm 0.84 \\
(-0.01 \pm 0.90)\end{array}$ & $\begin{array}{r}0.64 \pm 0.56 \\
(0.49 \pm 0.45)\end{array}$ \\
\hline EBAF & MERRA $\mathrm{t} 2 \mathrm{~m}$ & $\begin{array}{r}1.06 \pm 0.78 \\
(0.78 \pm 0.83)\end{array}$ & $\begin{array}{r}-0.08 \pm 0.71 \\
(-0.21 \pm 0.74)\end{array}$ & $\begin{array}{r}1.14 \pm 0.59 \\
(0.99 \pm 0.48)\end{array}$ \\
\hline MERRA & MERRA $\mathrm{t} 2 \mathrm{~m}$ & $\begin{array}{r}0.43 \pm 0.72 \\
(0.15 \pm 0.78)\end{array}$ & $\begin{array}{r}0.04 \pm 0.74 \\
(-0.09 \pm 0.76)\end{array}$ & $\begin{array}{r}0.39 \pm 0.52 \\
(0.24 \pm 0.45)\end{array}$ \\
\hline AIRS & MERRA $\mathrm{t} 2 \mathrm{~m}$ & N/A & N/A & $\begin{array}{r}0.44 \pm 0.57 \\
(0.29 \pm 0.50)\end{array}$ \\
\hline Terra & NCEP $\mathrm{t} 2 \mathrm{~m}$ & $\begin{array}{r}-0.34 \pm 0.79 \\
(-0.46 \pm 0.81)\end{array}$ & $\begin{array}{r}-0.28 \pm 0.73 \\
(-0.53 \pm 0.77)\end{array}$ & $\begin{array}{r}-0.06 \pm 0.59 \\
(0.07 \pm 0.48)\end{array}$ \\
\hline Aqua & NCEP $\mathrm{t} 2 \mathrm{~m}$ & $\begin{array}{r}0.12 \pm 0.76 \\
(0.00 \pm 0.82)\end{array}$ & $\begin{array}{r}-0.09 \pm 0.72 \\
(-0.33 \pm 0.77)\end{array}$ & $\begin{array}{r}0.21 \pm 0.59 \\
(0.34 \pm 0.47)\end{array}$ \\
\hline SSF AVG & NCEP $\mathrm{t} 2 \mathrm{~m}$ & $\begin{array}{r}-0.11 \pm 0.75 \\
(-0.23 \pm 0.79)\end{array}$ & $\begin{array}{r}-0.19 \pm 0.72 \\
(-0.43 \pm 0.76)\end{array}$ & $\begin{array}{r}0.08 \pm 0.57 \\
(0.20 \pm 0.45)\end{array}$ \\
\hline ECMWF & NCEP $\mathrm{t} 2 \mathrm{~m}$ & $\begin{array}{r}0.08 \pm 0.74 \\
(-0.04 \pm 0.81)\end{array}$ & $\begin{array}{r}-0.17 \pm 0.77 \\
(-0.42 \pm 0.83)\end{array}$ & $\begin{array}{r}0.26 \pm 0.52 \\
(0.38 \pm 0.42)\end{array}$ \\
\hline EBAF & NCEP $\mathrm{t} 2 \mathrm{~m}$ & $\begin{array}{r}-0.10 \pm 0.74 \\
(-0.22 \pm 0.78)\end{array}$ & $\begin{array}{r}-0.26 \pm 0.66 \\
(-0.50 \pm 0.68)\end{array}$ & $\begin{array}{r}0.16 \pm 0.58 \\
(0.28 \pm 0.47)\end{array}$ \\
\hline MERRA & NCEP $\mathrm{t} 2 \mathrm{~m}$ & $\begin{array}{r}0.17 \pm 0.67 \\
(0.06 \pm 0.72)\end{array}$ & $\begin{array}{r}0.04 \pm 0.68 \\
(-0.20 \pm 0.71)\end{array}$ & $\begin{array}{r}0.13 \pm 0.49 \\
(0.26 \pm 0.41)\end{array}$ \\
\hline AIRS & NCEP $\mathrm{t} 2 \mathrm{~m}$ & N/A & N/A & $\begin{array}{r}0.38 \pm 0.53 \\
(0.51 \pm 0.45)\end{array}$ \\
\hline
\end{tabular}

* HadCRUT4 is only available up to December 2010. 
time of the noise (Spencer and Braswell, 2008), this could lead to a positive bias in the diagnosed cloud feedback. This is because the cloud radiative effects, which may even originate in response to (for example) changing ocean temperatures in another region, would necessarily influence surface temperatures, but this method would always incorrectly classify the increased (decreased) downward radiation as a positive feedback to increasing (decreasing) temperatures in that region, rather than the cause. Of course, this bias only exists if the temperature response is correlated with the radiative effects, which in turn means the response must come within the decorrelation time of such effects. An attempt has been made to show that these fluctuations in the cloud forcing are insignificant relative to the variability in ocean heat exchange between layers, noting that the standard deviation of ocean heat flux from ARGO measurements down to the $700 \mathrm{~m}$ layer would correspond to a monthly forcing of $13 \mathrm{Wm}^{-2}$ and a ratio of $\sigma\left(\Delta F_{\text {ocean }}\right) / \sigma\left(\Delta R_{\text {cloud }}\right) \approx 20$ (Dessler, 2011). Estimating the heat flux of a more realistic $100 \mathrm{~m}$ mixed layer from ocean temperature anomalies (Levitus et al., 2009), however, results in a standard deviation of $2.1 \mathrm{Wm}^{-2}$ for 3month averages. Obviously, using a singular depth to represent the mixed layer is problematic due to the spatial and seasonal heterogeneity. Nonetheless, a lower value for mixedlayer heat capacity on these times scales is more in line with recent regressions, which have found that the relatively small variations associated with the solar cycle $\left(\sim 0.25 \mathrm{Wm}^{-2}\right)$ can be detected in global surface temperatures, with an instantaneous response of $\sim 0.4 \mathrm{~K} /\left(\mathrm{Wm}^{-2}\right)$ after only a month lag (Foster and Rahmstorf, 2011). If a similar efficacy were to exist for radiative noise due to cloud variations, this noise could significantly contaminate the cloud feedback estimate. The extent of this contamination thus depends on the amount non-feedback radiative variability, as well as the decorrelation time of the radiative noise produced.

Finally, Dessler (2010) notes that there is no correlation between the short- and long-term cloud feedbacks among models, so that the long-term feedback may be significantly higher or lower than that diagnosed from interannual variations. This fact, combined with the sensitivity of the estimated short-term feedback to methodological choices, suggests that diagnosing a climate-scale cloud feedback in this manner will require a substantially longer time period.

\section{Supplementary material related to this article is available online at: http://www.earth-syst-dynam.net/3/ 97/2012/esd-3-97-2012-supplement.zip.}

Acknowledgements. We thank the CERES team, and N. G. Loeb in particular for information regarding the datasets. We thank A. E. Dessler for guidance in reproducing his results, and Alexandra Jonko of Oregon State for her help in utilizing the radiative kernels. The reviewers of the manuscript provided numerous constructive comments in helping improve the paper. The AIRS data product was provided by the NASA Goddard Earth Sciences Data and Information Services Center (DISC). ECMWF ERAInterim data used in this study have been obtained from the ECMWF Data Server. NCEP Reanalysis data were retrieved from the NOAA Earth System Research Library Physical Sciences Division website at http://www.esrl.noaa.gov/. Global MERRA data used in this study were produced with the Giovanni online data system, developed and maintained by the NASA GES DISC at http://disc.sci.gsfc.nasa.gov/giovanni/.

Edited by: J. C. Hargreaves

\section{References}

Allan, R. P.: Combining satellite data and models to estimate cloud radiative effect at the surface and in the atmosphere, Meteorol. Appl., 18, 324-333, doi:10.1002/met.285, 2011.

Allan, R. P., Ringer, M. A., and Slingo, A.: Evaluation of moisture in the Hadley Centre Climate Model using simulations of HIRS water vapour channel radiances, Q. J. Roy. Meteorol. Soc., 129, 3371-3389, doi:10.1256/qj.02.217, 2003.

Andrews, T., Forster, P. M., Boucher, O., Bellouin, N., and Jones, A.: Precipitation, radiative forcing and global temperature change, Geophys. Res. Lett., 37, L14701, doi:10.1029/2010GL043991, 2010.

Bender, F. A.-M.: Planetary albedo in strongly forced climate, as simulated by the CMIP3 models, Theor. Appl. Climatol., 105, 529-535, doi:10.1007/s00704-011-0411-2, 2011.

Bony, S. R., Colman, R., Kattsov, V. M., Allan, R. P., Bretherton, C. S., Dufresne, J.-J., Hall, A., Hallegatte, S., Holland, M. M., Ingram, W., Randall, D. A., Soden, B. J., Tselioudis, G., and Webb, M. J.: How well do we understand and evaluate climate change feedback processes?, J. Climate, 19, 3445-3482, doi:10.1175/JCLI3819.1, 2006.

Brohan, P., Kennedy, J. J., Harris, I., Tett, S. F. B., and Jones, P. D.: Uncertainty estimates in regional and global observed temperature changes: A new dataset from 1850, J. Geophys. Res., 111, D12106, doi:10.1029/2005JD006548, 2006.

Cess, R. D. and Potter, G. L.: Exploratory studies of cloud radiative forcing with a general circulation model, Tellus, 39, 460-473, 1987.

Chahine, M. T., Pagano, T. S., Aumann, H. H., Atlas, R., Barnet, C., Blaisdell, J., Chen, L., Divakarla, M., Fetzer, E., Goldberg, M., Gautier, C., Granger, S., Hannon, S., Irion, F. W., Kakar, R., Kalnay, E., Lambrigtsen, B. H., Lee, S.-Y., Marshall, J. L., McMillan, W. W., McMillin, L., Olsen, E. T., Revercomb, H., Rosenkranz, P., Smith, W. L., Staelin, D., Strow, L. L., Susskind, J., Tobin, D., Wolf, W., and Zhou, L.: AIRS: Improving Weather Forecasting and Providing New Data on Greenhouse Gases, B. Am. Meteorol. Soc., 87, 911-926, 2006.

Davies, R. and Molloy, M.: Global cloud height fluctuations measured by MISR on Terra from 2000 to 2010, Geophys. Res. Lett., 39, L03701, doi:10.1029/2011GL050506, 2012.

Dee, D. P., Uppala, S. M., Simmons, A. J., Berrisford, P., Poli, P., Kobayashi, S., Andrae, U., Balmaseda, M. A., Balsamo, G., Bauer, P., Bechtold, P., Beljaars, A. C. M., van de Berg, L., Bidlot, J., Bormann, N., Delsol, C., Dragani, R., Fuentes, M., Geer, A. J., Haimberger, L., Healy, S. B., Hersbach, H., Hólm, E. V., Isaksen, L., Kållberg, P., Köhler, M., Matricardi, M., 
McNally, A. P., Monge-Sanz, B. M., Morcrette, J.-J., Park, B.K., Peubey, C., de Rosnay, P., Tavolato, C., Thépaut, J.-N., and Vitart, F.: The ERA-interim reanalysis: configuration and performance of the data assimilation system, data available at: http:// data-portal.ecmwf.int/data/d/interimmoda/levtype $=\mathrm{sfc} /$, last access: 4 January 2012, Q. J. Roy. Meteorol. Soc., 137, 553-597, doi:10.1002/qj.828, 2011.

Dessler, A. E.: A determination of the cloud feedback from climate variations over the past decade, Science, 330, 1523-1527, doi:10.1126/science.1192546, 2010.

Dessler, A. E.: Cloud variations and the Earth's energy budget, Geophys. Res. Lett., 38, L19701, doi:10.1029/2011GL049236, 2011.

Erlick, C. and Ramaswamy, V.: Note on the de?nition of clear sky in calculations of short wave cloud forcing, J. Geophys. Res., 108, 4156, doi:10.1029/2002JD002990, 2003.

Foster, G. and Rahmstorf, S.: Global temperature evolution 1979-2010, Environ. Res. Lett., 6, 044022, doi:10.1088/17489326/6/4/044022, 2011.

Hansen, J., Ruedy, R., Sato, M., and Lo, K.: Global surface temperature change, Rev. Geophys., 48, RG4004, doi:10.1029/2010RG000345, 2010.

John, V. O., Allan, R. P., and Soden, B. J.:, How robust are observed and simulated precipitation responses to tropical ocean warming?, Geophys. Res. Lett., 36, L14702, doi:10.1029/2009GL038276, 2009.

Jones, P. D., Lister, D. H., Osborn, T. J., Harpham, C., Salmon, M., and Morice, C. P.: Hemispheric and large-scale land-surface air temperature variations: An extensive revision and an update to 2010, J. Geophys. Res., 117, D05127, doi:10.1029/2011JD017139, 2012.

Kaufmann, R. K., Kauppi, H., Mann, M. L., and Stock, J. H.: Reconciling anthropogenic climate change with observed temperature 1998-2008, P. Natl. Acad. Sci., 108, 11790-11793, doi:10.1073/pnas.1102467108, 2011.

Lee, J., Yang, P., Dessler, A. E., Gao, B.-C., and Platnick, S.: Distribution and Radiative Forcing of Tropical Thin Cirrus Clouds, J. Atmos. Sci., 66, 3721-3731, doi:10.1175/2009JAS3183.1, 2009.

Levitus, S., Antonov, J. I., Boyer, T. P., Locarnini, R. A., Garcia, H. E., and Mishonov, A. V.: Global ocean heat content 19952008 in light of recently revealed instrumentation problems, data available from: http://www.nodc.noaa.gov/OC5/3M_HEAT CONTENT/anomaly_data.html, last access: 14 September 2011, Geophys. Res. Lett., 36, L07608, doi:10.1029/2008GL037155, 2009.

Loeb, N. G., Wielicki, B. A., Doelling, D. R. , Smith, G. L., Keyes, D. F., Kato, S., Manlo-Smith, N., and Wong, T.: Toward Optimal Closure of the Earth's TOA Radiation Budget, J. Climate, 22, 748-766, doi:10.1175/2008JCLI2637.1, 2009.

Loeb, N. G., Kato, S., Su, W., Wong, T., Rose, F. G., Doelling, D. R., Norris, J. R., and Huang, X.: Advances in Understanding Top-ofAtmosphere Radiation Variability from Satellite Observations, Surv. Geophys., 33, 359-385, doi:10.1007/s10712-012-9175-1, 2012.

Rienecker, M. M., Suarez, M. J., Gelaro, R., Todling, R., Bacmeister, J., Liu, E., Bosilovich, M. G., Schubert, S. D., Takacs, L., Kim, G.-K., Bloom, S., Chen, J., Collins, D., Conaty, A., da Silva, A., Gu, W., Joiner, J., Koster, R. D., Lucchesi, R., Molod, A., Owens, T., Pawson, S., Pegion, P., Redder, C. R., Reichle, R., Robertson, F. R., Ruddick, A. G., Sienkiewicz, M., and Woollen, J.: MERRA - NASA's Modern-Era Retrospective Analysis for Research and Applications, J. Climate, 24, 36243648, doi:10.1175/JCLI-D-11-00015.1, 2011.

Shell, K. M., Kiehl, J. T., and Shields, C. A.: Using the radiative kernel technique to calculate climate feedbacks in NCAR's Community Atmospheric Model, J. Climate, 21, 2269-2282, doi:10.1175/2007JCLI2044.1, 2008.

Smith, T. M., Reynolds, R. W., Peterson, T. C., and Lawrimore, J.: Improvements to NOAA's Historical Merged Land-Ocean Surface Temperature Analysis (1880-2006), data available at: ftp://ftp.ncdc.noaa.gov/pub/data/anomalies/monthly.land_ocean. 90S.90N.df_1901-2000mean.dat, last access: 4 January 2012, J. Climate, 21, 2283-2293, doi:10.1175/2007JCLI2100.1, 2008.

Soden, B. J., Held, I. M., Colman, R., Shell, K. M., Kiehl, J. T., and Shields, C. A: Quantifying climate feedbacks using radiative kernels, J. Climate, 21, 3504-3520, doi:10.1175/2007JCLI2110.1, 2008.

Sohn, B.-J. and Bennartz, R.: Contribution of water vapor to observational estimates of longwave cloud radiative forcing, J. Geophys. Res., 113, D20107, doi:10.1029/2008JD010053, 2008.

Solomon, S., Daniel, J. S., Neely III, R. R., Vernier, J. P., Dutton, E. G., and Thomason, L. W.: The Persistently Variable "Background" Stratospheric Aerosol Layer and Global Climate Change, Science, 333, 866-870, doi:10.1126/science.1206027, 2011.

Spencer, R. W. and Braswell, W. D.: Potential biases in feedback diagnosis from observational data: A simple model demonstration, J. Climate, 21, 5624-5628, doi:10.1175/2008JCLI2253.1, 2008.

Spencer, R. W., Braswell, W. D., Christy, J. R., and Hnilo, J.: Cloud and radiation budget changes associated with tropical intraseasonal oscillations, Geophys. Res. Lett., 34, L15707, doi:10.1029/2007GL029698, 2007.

Sun, W., Lin, B., Hu, Y., Lukashin, C., Kato, S., and Liu, Z.: On the consistency of CERES longwave flux and AIRS temperature and humidity profiles, J. Geophys. Res., 116, D17101, doi:10.1029/2011JD016153, 2011.

Wielicki, B. A., Barkstrom, B. R., Baum, B. A., Charlock, T. P., Green, R. N., Kratz, D. P, Lee, R. B., Minnis, P., Smith, G. L., Wong, T., Young, D. F., Cess, R. D., Coakley, J. A., Crommelynck, A. D., Donner, L., Kandel, R., King, M. D., Miller, A. J., Ramanathan, V., Randall, D. A., Stowe, L. L., and Welch, R. M.: Clouds and the Earth's Radiant Energy System (CERES): Algorithm overview, data available at: http://ceres.larc.nasa.gov/ order_data.php, last access: 12 January 2012, IEEE T. Geosci. Remote, 36, 1127-1141, doi:10.1109/36.701020, 1998.

Zelinka, M. D. and Hartmann, D. L.: The observed sensitivity of high clouds to mean surface temperature anomalies in the tropics, J. Geophys. Res., 116, D23103, doi:10.1029/2011JD016459, 2011.

Zhang, M. H., Lin, W. Y., Klein, S. A., Bacmeister, J. T., Bony, S., Cederwall, R. T., Del Genio, A. D., Hack, J. J., Loeb, N. G., Lohmann, U., Minnis, P., Musat, I., Pincus, R., Stier, P., Suarez, M. J., Webb, M. J., and Wu, J. B.: Comparing clouds and their seasonal variations in 10 atmospheric general circulation models with satellite measurements, J. Geophys. Res., 110, D15S02, doi:10.1029/2004JD005021, 2005. 